\title{
Hubungan Pola Konsumsi Minuman Berkafein dengan Fungsi Kognitif pada Lansia di GKJ Gondokusuman Yogyakarta
}

\author{
Dewa K. Putra, ${ }^{1}$ Yoseph L. Samodra, ${ }^{2}$ Daniel C. A. Nugroho ${ }^{3}$
}

\author{
${ }^{1}$ Bachelor Program of Medicine, Faculty of Medicine, Duta Wacana Christian University \\ Yogyakarta \\ ${ }^{2}$ Department of Biochemistry and Nutrition, Faculty of Medicine, Duta Wacana Christian \\ University Yogyakarta \\ ${ }^{3}$ Department of Medical Information and Technology Faculty of Medicine, Duta Wacana \\ Christian University Yogyakarta \\ Email: Dwketutkartika@gmail.com
}

\begin{abstract}
Elderly population which continues to increase in number every year causes various social, economic, and health problems inter alia cognitive dysfunction. One of the efforts that can prevent and slow down the decline in cognitive function is consuming caffeinated beverages. This study was aimed to evaluate the relationship between the pattern of caffeinated beverage consumption and cognitive function among the elderly at GKJ Gondokusuman in Yogyakarta. This was an analytical observational study with a cross-sectional design. We used the modified Food Frequency Questionnaire (FFQ) to measure the consumption patterns of caffeinated beverage meanwhile the cognitive function was measured by using the Mini Mental State Examination (MMSE) and the Clock Drawing Test (CDT). Sample size was determined by using the total sampling method. There were 54 samples of elderly population. Data were analyzed by using the Spearman correlation test which obtained $(\mathrm{p}=0.023 ; \mathrm{r}=-0.309)$ for the relationship between caffeinated beverage consumption pattern and cognitive function measured with the MMSE, and ( $p=0.075 ; r=0.244$ ) for the relationship between caffeinated beverage consumption pattern and cognitive function measured with the the CDT. In conclusion, there was a significant relationship between caffeinated beverage consumption pattern and cognitive function measured with the MMSE, however, there was no significant relationship between caffeinated beverage consumption pattern and cognitive function measured with the the CDT.
\end{abstract}

Keywords: caffeinated beverage consumption patterns, cognitive function, elderly

\begin{abstract}
Abstrak: Populasi lanjut usia (lansia) yang terus mengalami peningkatan setiap tahunnya menimbulkan berbagai masalah sosial, ekonomi, dan kesehatan, antara lain gangguan fungsi kognitif. Salah satu upaya untuk mencegah dan memperlambat penurunan fungsi kognitif ialah dengan minuman yang mengandung kafein. Penelitian ini bertujuan untuk mengetahui adanya hubungan pola konsumsi minuman berkafein dengan fungsi kognitif lansia di GKJ Gondokusuman. Jenis penellitian ialah observasional analitik dan desain potong lintang. Pola konsumsi minuman berkafein diukur dengan Food Frequency Questionnaire (FFQ) yang telah dimodifikasi, sedangkan fungsi kognitif diukur dengan Mini Mental (MMSE) dan Clock Drawing Test (CDT). Penghitungan besar sampel dengan metode total sampling mendapatkan 54 sampel dari populasi, yaitu lansia di GKJ Gondokusuman. Hasil analisis data menggunakan uji Spearman terhadap hubungan antara pola konsumsi minuman berkafein dengan fungsi kognitif yang diukur dengan MMSE mendapatkan ( $\mathrm{p}=0,023 ; \mathrm{r}=-0,309)$ sedangkan dengan fungsi kognitif yang diukur dengan kuisioner CDT mendapatkan ( $\mathrm{p}=0,075 ; \mathrm{r} 0,244)$. Simpulan penelitian ini ialah terdapat hubungan bermakna antara pola konsumsi minuman berkafein dengan fungsi kognitif lansia yang dinilai menggunakan MMSE, namun tidak terdapat hubungan bermakna dengan fungsi kognitif lansia yang dinilai menggunakan CDT.
\end{abstract}

Kata kunci: pola konsumsi minuman berkafein, fungsi kognitif, lansia 


\section{PENDAHULUAN}

Populasi lansia yang terus mengalami peningkatan setiap tahunnya telah menimbulkan berbagai masalah sosial, ekonomi, dan kesehatan. Dilihat dari aspek kesehatan, seiring dengan bertambahnya usia maka usia lanjut akan menjadi lebih rentan terhadap berbagai keluhan fisik maupun mental, karena proses degeneratif yang akan menyebabkan kemunduran dalam peran sosialnya. Salah satu masalah kesehatan yang sering muncul pada usia lanjut adalah gangguan fungsi kognitif. ${ }^{1}$

Gangguan fungsi kognitif saat ini masih menjadi masalah kesehatan yang cukup serius karena dapat berdampak pada aspek psikologis, sosial, dan ekonomi. Gangguan fungsi kognitif dapat berupa gangguan cara berpikir, tidak mampu menganalisis bahasa, tidak mampu mengenal persamaan, tidak mampu melakukan kalkulasi, dan tidak mampu memahami konsep. ${ }^{2}$ Pada keadaan tersebut terjadi kesulitan dalam memecahkan masalah, pengambilan keputusan, gangguan komunikasi, gangguan mobilitas, perawatan diri sendiri, interaksi sosial, dan aktivitas sehari-hari. Berbagai gangguan tersebut pada akhirnya akan menurunkan kualitas hidup seseorang. ${ }^{3}$

Salah satu upaya yang dapat dilakukan untuk mencegah dan memperlambat penurunan fungsi kognitif ialah dengan pemberian asupan makanan, berupa makanan atau minuman yang mengandung kafein. ${ }^{4}$ Kafein merupakan zat psikoaktif yang paling sering dikonsumsi oleh $80 \%$ populasi dunia dan 90\% populasi di Amerika Utara. ${ }^{5}$ Kafein tersedia secara luas, banyak dipasarkan, dan dapat diterima secara sosial, bahkan beberapa kalangan meyakini bahwa minuman berkafein dapat meningkatkan performa dan keadaan mental dengan mengurangi atau menghilangkan rasa kantuk. ${ }^{6}$ Berdasarkan latar belakang ini, penulis tertarik untuk mengetahui hubungan pola konsumsi minuman berkafein dengan fungsi kognitif pada lansia di GKJ Gondokusuman Yogyakarta.

\section{METODE PENELITIAN}

Penelitian ini menggunakan metode analitik observasional dengan desain potong lintang. Populasi penelitian ialah lanjut usia yang mengikuti pemeriksaan di GKJ Gondokusuman. Pengambilan sampel dilakukan dengan menggunakan teknik consecutive sampling dan didapatkan total subyek sebanyak 54 orang lansia ( $>60$ tahun). Pengambilan sampel dilakukan dengan pengisian kuesioner Food Frequency Questionnaire (FFQ) yang sudah divalidasi, Mini Mental State Examination (MMSE), dan Clock Drawing Test (CDT). Pada penelitian ini data dianalisis secara univariat dan bivariat untuk mengetahui korelasi antara pola konsumsi minuman berkafein dengan fungsi kognitif. Sebelumnya data telah diuji normalitasnya untuk mengetahui sebaran data menggunakan uji Kolmogrov Smirnov. Data yang tidak terdistribusi normal dilanjutkan dengan menggunakan metode analisis uji korelasi Spearman. Untuk data kategorik digunakan uji chi square, dan bila paling tidak ada satu sel yang mempunya nilai expected kurang dari lima maka digunakan uji Fisher.

\section{HASIL PENELITIAN}

Karakteristik variabel yang diamati dalam penelitian ini ialah jenis kelamin, riwayat pendidikan, riwayat hipertensi, riwayat diabetes melitus (DM), fungsi kognitif, usia, pola konsumsi minuman berkafein, dan jumlah cangkir minuman berkafein. Tabel 1 memperlihatkan distribusi frekuensi karakteristik subyek penelitian sesuai dengan variabel penelitian

Tabel 2 memperlihatkan bahwa kisaran usia lansia yang mengikuti penelitian ialah 60-83 tahun dengan rerata usia 68 tahun (SD $\pm 5,673)$ dan nilai tengah 67,50 tahun. Pola konsumsi minuman berkafein dilihat dari jenis minuman berkafein dan frekuensi pada tiap harinya. Rerata lansia mengonsumsi minuman berkafein 1,6893 kali/hari $(\mathrm{SD} \pm 1,39)$ dan nilai tengah $1,2800 \mathrm{kali} / \mathrm{hari}$. Ditemukan bahwa nilai minimum pola konsumsi minuman berkafein yaitu 0 dan nilai maksimumnya 7,00. Lansia yang mengikuti penelitian rata-rata mengonsumsi minuman berkafein 2,2963 cangkir dalam sehari $(\mathrm{SD} \pm 1,19163)$ dengan nilai tengah 2,00 . Untuk nilai minimum jumlah cangkir 
minuman berkafein sehari didapatkan 0 , sedangkan nilai maksimum didapatkan 6 cangkir dalam sehari.

Tabel 3 memperlihatkan hasil uji bivariat variabel jenis kelamin, riwayat hipertensi, riwayat DM, dan riwayat pendidikan dengan fungsi kognitif dinilai dengan MMSE yang menunjukkan tidak terdapat hubungan bermakna secara statistik $(\mathrm{p}>0,05)$.
Tabel 4 memperlihatkan hasil uji bivariat antara riwayat pendidikan dengan fungsi kognitif $(\mathrm{p}=0,002)$ yang menunjukkan terdapat hubungan bermakna secara statistik antara riwayat pendidikan dengan fungsi kognitif. Namun, variabel jenis kelamin, riwayat hipertensi, dan riwayat DM tidak memiliki hubungan bermakna secara statistik dengan fungsi kognitif yang dinilai dengan CDT ( $\mathrm{p}>0,05)$.

Tabel 1. Distribusi frekuensi karakteristik subjek penelitian

\begin{tabular}{ccc}
\hline Variabel Lansia & Frekuensi & $\begin{array}{c}\text { Persentase } \\
(\%)\end{array}$ \\
\hline Jenis kelamin & 16 & 70,4 \\
Laki-laki & 38 & 29,6 \\
Perempuan & 32 & 59,3 \\
Riwayat pendidikan & 22 & 40,7 \\
$\leq 12$ tahun & & \\
$>12$ tahun & 21 & 38,9 \\
Riwayat hipertensi & 33 & 61,1 \\
Ya & & \\
Tidak & 16 & 29,6 \\
Riwayat DM & 38 & 70,4 \\
Ya & & \\
Tidak & 48 & 88,9 \\
Fungsi kognitif (MMSE) & 6 & 11,1 \\
Normal & & \\
Buruk & 39 & 72,2 \\
Fungsi kognitif (CDT) & 15 & 27,8 \\
Normal & 54 & 100 \\
Buruk & & \\
Total & &
\end{tabular}

Tabel 2. Nilai rerata, standar deviasi, median, minimum, dan maksimum dari usia, fungsi kognitif (MMSE), fungsi kognitif (CDT), pola konsumsi minuman berkafein, dan jumlah cangkir minuman berkafein pada lansia di GKJ Gondokusuman

\begin{tabular}{|c|c|c|c|c|c|}
\hline Variabel & Rerata & $\begin{array}{c}\text { Standar } \\
\text { Deviasi }\end{array}$ & Median & Min. & Maks. \\
\hline Usia $(n=54)$ & $\begin{array}{l}68,31 \\
\text { tahun }\end{array}$ & 5,673 & $\begin{array}{l}67,50 \\
\text { tahun }\end{array}$ & 60 tahun & 83 tahun \\
\hline $\begin{array}{l}\text { Pola konsumsi minuman } \\
\text { berkafein }(n=54)\end{array}$ & $\begin{array}{c}1,6893 \\
\text { kali/hari }\end{array}$ & 1,39435 & $\begin{array}{c}1,2800 \\
\text { kali/hari }\end{array}$ & $\begin{array}{c}0,00 \\
\text { kali/hari }\end{array}$ & $\begin{array}{c}\text { 7,00 } \\
\text { kali/hari }\end{array}$ \\
\hline $\begin{array}{l}\text { Jumlah cangkir minuman } \\
\text { berkafein }(n=54)\end{array}$ & $\begin{array}{l}2,2963 \\
\text { cangkir }\end{array}$ & $\begin{array}{l}1,19163 \\
\text { cangkir }\end{array}$ & $\begin{array}{c}2,00 \\
\text { cangkir }\end{array}$ & $\begin{array}{c}0 \\
\text { cangkir }\end{array}$ & $\begin{array}{c}6 \\
\text { cangkir }\end{array}$ \\
\hline $\operatorname{MMSE}(\mathrm{n}=54)$ & 27,19 & 2,720 & 28,00 & 17 & 30 \\
\hline $\operatorname{CDT}(\mathrm{n}=54)$ & 2,93 & 0,843 & 3,00 & 1 & 4 \\
\hline
\end{tabular}


Tabel 3. Analisis bivariat hubungan variabel kategori dengan fungsi kognitif (skor MMSE)

\begin{tabular}{|c|c|c|c|c|c|c|c|c|}
\hline \multirow{3}{*}{ No } & \multicolumn{7}{|c|}{ Fungsi Kognitif (MMSE) } & \multirow{3}{*}{$\begin{array}{c}\text { Nilai } \\
\mathbf{p}\end{array}$} \\
\hline & \multirow[t]{2}{*}{ Variabel } & \multicolumn{2}{|c|}{ Buruk } & \multicolumn{2}{|c|}{ Normal } & \multirow[t]{2}{*}{ OR } & \multirow[t]{2}{*}{ CI 95\% } & \\
\hline & & $\mathrm{N}$ & $\%$ & $\mathrm{~N}$ & $\%$ & & & \\
\hline \multirow[t]{3}{*}{1} & Jenis kelamin $^{2}$ & & & & & 1,214 & $0,199-7,404$ & 1,000 \\
\hline & Laki-laki & 2 & 12,5 & 14 & 87,5 & & & \\
\hline & Perempuan & 4 & 10,5 & 34 & 89,5 & & & \\
\hline \multirow[t]{3}{*}{2} & Riwayat hipertensi ${ }^{2}$ & & & & & 1,222 & $1,041-1,435$ & 0,71 \\
\hline & $\mathrm{Ya}$ & 0 & 0,0 & 21 & 100 & & & \\
\hline & Tidak & 6 & 18,2 & 27 & 81,8 & & & \\
\hline \multirow[t]{3}{*}{3} & Riwayat $\mathrm{DM}^{2}$ & & & & & 1,188 & $1,035-1,363$ & 0,163 \\
\hline & Ya & 0 & 0,0 & 16 & 100 & & & \\
\hline & Tidak & 6 & 15,8 & 32 & 84,2 & & & \\
\hline \multirow[t]{3}{*}{4} & Riwayat pendidikan $^{2}$ & & & & & 1,429 & $0,238-8,571$ & 1,000 \\
\hline & $\leq 12$ tahun & 4 & 12,5 & 28 & 87,5 & & & \\
\hline & $>12$ tahun & 2 & 9,1 & 20 & 90,9 & & & \\
\hline
\end{tabular}

Keterangan: ${ }^{2} \mathrm{Uji}$ Fisher

Tabel 4. analisis bivariat hubungan variabel kategori dengan fungsi kognitif (Skor CDT)

\begin{tabular}{|c|c|c|c|c|c|c|c|c|}
\hline \multirow{3}{*}{ No } & \multirow{3}{*}{ Variabel } & \multicolumn{4}{|c|}{ Fungsi Kognitif (CDT) } & \multirow{3}{*}{ OR } & \multirow{3}{*}{ CI $95 \%$} & \multirow{3}{*}{$\begin{array}{c}\text { Nilai } \\
\mathbf{p}\end{array}$} \\
\hline & & \multicolumn{2}{|c|}{ Buruk } & \multicolumn{2}{|c|}{ Baik } & & & \\
\hline & & $\mathrm{N}$ & $\%$ & $\mathrm{~N}$ & $\%$ & & & \\
\hline \multirow[t]{3}{*}{1} & Jenis kelamin $^{2}$ & & & & & 0,275 & $0,054-1,397$ & 0,18 \\
\hline & Laki-laki & 2 & 12,5 & 14 & 87,5 & & & 2 \\
\hline & Perempuan & 13 & 34,2 & 25 & 65,8 & & & \\
\hline \multirow[t]{3}{*}{2} & Riwayat hipertensi $^{1}$ & & & & & 0,471 & $0,127-1,740$ & 0,25 \\
\hline & $\mathrm{Ya}$ & 4 & 19,0 & 17 & 81,0 & & & 3 \\
\hline & Tidak & 11 & 33,3 & 22 & 66,7 & & & \\
\hline \multirow[t]{3}{*}{3} & Riwayat $\mathrm{DM}^{2}$ & & & & & 1,273 & $0,354-4,578$ & 0,74 \\
\hline & $\mathrm{Ya}$ & 5 & 31,3 & 11 & 68,8 & & & 7 \\
\hline & Tidak & 10 & 26,3 & 28 & 73,7 & & & \\
\hline \multirow[t]{3}{*}{4} & Riwayat pendidikan $^{1}$ & & & & & 16,333 & $1,952-136,647$ & 0,00 \\
\hline & $\leq 12$ tahun & 14 & 43,8 & 18 & 56,3 & & & $2 *$ \\
\hline & $>12$ tahun & 1 & 4,5 & 21 & 95,5 & & & \\
\hline
\end{tabular}

Keterangan: ${ }^{1}$ : Uji Chi-Square $\quad{ }^{2}$ : Uji Fisher

Tabel 5 memperlihatkan hasil analisis uji Spearman dengan nilai $\mathrm{p}<0,05$ yang menunjukkan terdapat hubungan bermakna antara pola konsumsi minuman berkafein $(\mathrm{p}=0,023)$ dan jumlah cangkir minuman berkafein $(\mathrm{p}=0,002)$ dengan fungsi kognitif yang diukur dengan MMSE. Selain itu terdapat hubungan bermakna antara jumlah cangkir minuman berkafein dengan fungsi kognitif yang diukur dengan CDT $(\mathrm{p}=0,028)$. 
Tabel 5. Hasil uji korelasi Spearman

\begin{tabular}{lll}
\hline \multicolumn{1}{c}{$\mathbf{n = 5 4}$} & \multicolumn{2}{c}{ Fungsi Kognitif } \\
& MMSE & CDT \\
\hline Usia & $\mathrm{r}=-0,081$ & $\mathrm{r}=-0,189$ \\
& $\mathrm{p}=0,559$ & $\mathrm{p}=0,171$ \\
Pola konsumsi & $\mathrm{r}=-0,309$ & $\mathrm{r}=0,244$ \\
minuman berkafein & $\mathrm{p}=0,023^{*}$ & $\mathrm{p}=0,075$ \\
Jumlah cangkir minuman berkafein & $\mathrm{r}=-0,418$ & $\mathrm{r}=0,299$ \\
& $\mathrm{p}=0,002^{*}$ & $\mathrm{p}=0,028^{*}$ \\
\hline
\end{tabular}

\section{BAHASAN}

Hasil penelitian ini mendapatkan adanya hubungan bermakna antara pola konsumsi minuman berkafein dengan fungsi kognitif lansia yang dinilai dengan kusioner MMSE ( $\mathrm{p}=0,023 ; \mathrm{r}=-0,309$ ) sedangkan pada penilaian dengan kuisioner CDT didapatkan hasil berbeda yaitu tidak terdapat hubungan antara pola konsumsi minuman berkafein dengan fungsi kognitif lansia ( $\mathrm{p}=0,075$; $\mathrm{r}=0,244$ ). Analisis hubungan jumlah cangkir minuman berkafein dengan fungsi kognitif lansia menunjukkan adanya hubungan bermakna antara jumlah cangkir minuman berkafein dengan fungsi kognitif ( $\mathrm{p}=0,002$; $\mathrm{r}=-0,418$ dengan kuisioner MMSE dan $\mathrm{p}=$ 0,028; $r=0,299$ dengan kuisioner CDT). Penelitian sebelumnya yang dilakukan oleh Sachio $^{7}$ menyatakan bahwa terdapat hubungan bermakna antara konsumsi kafein dan fungsi kognitif pada lansia; selain itu fungsi kognitif normal lebih banyak didapatkan pada lansia yang mengonsumsi kafein dengan dosis tinggi (>200mg/hari). Hasil penelitian Sachio didukung oleh penelitian yang dilakukan oleh Cakir et $\mathrm{al}^{8}$ di Istanbul, Turkey yang menyimpulkan bahwa pemberian kafein jangka panjang dapat mencegah terjadinya penurunan fungsi kognitif melalui berkurangnya produksi radikal bebas, yaitu malondialdehyde, lucigenin, dan superoxide dismutase. Penelitian tersebut juga menunjukkan bahwa kafein memiliki efek anti oksidan. ${ }^{8}$ West et al $^{9}$ di New York melaporkan bahwa terdapat hubungan antara konsumsi kafein dengan fungsi kognitif lansia yaitu lansia yang mengonsumsi kafein lebih banyak memiliki fungsi kognitif yang lebih baik $(\mathrm{p}=0,018)$.
Penelitian ini juga mengasumsikan bahwa peningkatan fungsi kognitif tersebut terjadi akibat peningkatan volume gray matter (GM) dari otak. Pada penelitian tersebut juga didapatkan adanya hubungan antara konsumsi kafein dengan volume GM yaitu individu yang lebih banyak mengonsumsi kafein memiliki volume GM yang lebih besar $(p=0,033) .{ }^{9}$ Berbeda halnya dengan hasil penelitian yang dilakukan oleh Zhou et $\mathrm{al}^{10}$ yaitu penelitian meta-analisis dengan randomisasi Mendelian yang menggunakan data 415.530 responden dari 10 kohort berbeda yang dilakukan di berbagai negara di benua Eropa yang menyimpulkan bahwa tidak terdapat bukti kuat yang menunjukkan adanya hubungan antara konsumsi kafein jangka panjang dengan fungsi kognitif dan memori pada lansia. Hasil serupa juga ditunjukkan oleh penelitian oleh Perry et $\mathrm{al}^{11}$ di Massachusetts, Amerika Serikat yaitu penelitian prospektif yang melibatkan perempuan berusia 56-83 tahun. Perry et $\mathrm{al}^{11}$ menyatakan bahwa tidak terdapat hubungan antara konsumsi kafein dengan fungsi kognitif dan tidak terdapat efek protektif kafein bagi fungsi kognitif lansia perempuan.

Terdapat dua penelitian dengan desain yang jauh lebih baik dibandingkan penelitian lainnya yang sejalan dengan penelitian ini yaitu penelitian oleh Zhou et $\mathrm{al}^{10}$ dan Perry et $\mathrm{al}^{11}$. Kedua penelitian tersebut menunjukkan bahwa tidak terdapat hubungan antara pola konsumsi minuman berkafein dengan fungsi kognitif. Namun, pada penelitian ini instrumen Food Frequency Questionnaire (FFQ) hanya menggambarkan jenis minuman dan frekuensinya 
saja, tetapi tidak memaparkan kadar kafein dari pola konsumsi minuman berkafein yang dapat memengaruhi fungsi kognitif.

Hasil analisis hubungan antara riwayat pendidikan dengan fungsi kognitif yang dinilai dengan kusioner MMSE mendapatkan $\mathrm{p}=1,000$ sedangkan yang dinilai dengan kuisioner CDT mendapatkan $\mathrm{p}=0,002$. Tingkat pendidikan seseorang merupakan faktor risiko terjadinya demensia terutama penyakit Alzheimer, yaitu semakin rendah tingkat pendidikan seseorang maka semakin tinggi risiko terkena demensia Alzheimer. Pada individu dengan tingkat pendidikan rendah akan lebih cepat terjadi penurunan fungsi kognitif dibandingkan dengan yang mempunyai tingkat pendidikan tinggi. ${ }^{12}$ Hasil penelitian ini menunjukkan bahwa tidak terdapat hubungan antara riwayat pendidikan dengan fungsi kognitif yang dinilai dengan kuisioner MMSE $(p=1,000)$; hal ini dapat disebabkan karena variasi terhadap MMSE dipengaruhi oleh variabel demografi, yaitu skor menurun pada usia lanjut dan tingkat pendidikan yang lebih rendah. Pada penelitian ini, subyek lansia rata-rata berpendidikan tinggi.

Hasil analisis terhadap hubungan antara jenis kelamin dengan fungsi kognitif, mendapatkan nilai $\mathrm{p}>0,05$ yang berarti tidak terdapat hubungan bermakna antara jenis kelamin dan fungsi kognitif. Perempuan berisiko lebih tinggi dari laki-laki untuk mengalami gangguan fungsi kognitif seperti demensia Alzheimer, karena perempuan memiliki angka harapan hidup yang lebih tinggi, sedangkan laki-laki berisiko lebih tinggi untuk mengalami demensia vaskuler. Hal ini karena laki-laki cenderung melakukan kebiasaan yang dapat memicu terjadinya gangguan vaskuler seperti merokok dan mengonsumsi alkohol. Menopause pada lansia juga merupakan konsekuensi dari penuaan. Menopause dan hilangnya hormon ovarium merupakan salah satu faktor penurunan memori. Hipokampus pada wanita mengeluarkan hormon seperti estrogen sebagai faktor tropik selama dewasa. Kekurangan estrogen setelah menopause mengakibatkan neuron menjadi lebih rapuh dan memperburuk kemunduran memori. ${ }^{13}$
Perbedaan hasil penelitian ini dengan penelitian lainnya dapat disebabkan karena tidak seimbangnya perbandingan jumlah subyek laki-laki dan perempuan.

Berdasarkan hasil analisis antara riwayat hipertensi dengan fungsi kognitif lansia, didapatkan nilai $\mathrm{p}>0,05$ yang menunjukkan tidak adanya hubungan bermakna antara riwayat hipertensi dengan fungsi kognitif. Telah diketahui bahwa hipertensi mengganggu sirkulasi aliran darah otak yang dapat menyebabkan gangguan fungsi, salah satunya ialah gangguan fungsi kognitif. Salah satu komponen fungsi kognitif atensi merupakan kemampuan individu dalam kegiatan memusatkan perhatian pada suatu hal dan mengabaikan hal lain yang tidak sedang dipikirkan. Atensi dikontrol oleh kortek frontal yang berhubungan dengan penglihatan, kemudian pada kortek parietal dan pada kolikulus superior. Bila terdapat lesi pada region ini maka akan terjadi gangguan fungsi atensi. ${ }^{14}$ Subjek yang menyandang hipertensi esensial cenderung mengalami abnormalitas susunan saraf, terutama integritas lobus frontalis (kerusakan korteks prefrontal, hiperintensitas substansia alba) dibandingkan kelompok kontrol sehingga didapatkan hasil fungsi kognitif yang lebih buruk. ${ }^{15}$. Hasil yang tidak sejalan dengan teori dapat dikaitkan dengan adanya hipertensi terkontrol karena subjek mengonsumsi obat antihipertensi. Rouch et al $^{16}$ menyatakan bahwa obat antihipertensi menurunkan risiko terjadinya gangguan fungsi kognitif seperti demensia dan penyakit Alzheimer, khususnya obatobatan jenis calcium channel blocker (CCB) dan angiotensin receptor blocker (ARB) yang dapat mengurangi risiko, perkembangan gangguan kognitif dan demensia dengan cara menurukan tekanan darah dan memengaruhi efek saraf tertentu.

Hasil analisis hubungan antara riwayat DM dengan fungsi kognitif lansia memperoleh nilai $p>0,05$ yang berarti tidak terdapat hubungan bermakna antara riwayat DM dengan fungsi kognitif. Hal ini tidak sejalan dengan teori dan penelitian sebelumnya yang menyatakan terdapat hubungan antara DM dengan fungsi kognitif. Diabetes 
melitus menyebabkan aterosklerosis oleh karena apolipoprotein E (ApoE) sebagai transpor kolesterol meningkat sehingga menyebabkan plak neuritik di hipokampus yang mengganggu fungsi kognitif. Selain itu, hiperglikemia dapat menyebabkan efek toksik langsung melalui stres oksidatif dan akumulasi advanced glycation end products (AGEs) yang merusak jaringan otak di hipokampus. Penyandang DM tipe 2 selama $\geq 8$ tahun berisiko $87 \%$ terjadi penurunan fungsi kognitif terutama untuk kemampuan kognitif global, memori episodik, semantik, visuospasial, dan kecepatan persepsi. ${ }^{17,18}$ Hasil ini tidak sejalan dengan teori yang mungkin disebabkan karena perbedaan cara penilaian dan pengategorian fungsi kognitif serta cara penentuan DM. Pada subyek penelitian ini, yang membuat diagnosis DM ialah petugas kesehatan dan kemungkinan diagnosis DM juga pada subyek penelitian terkontrol karena hasil medikasi antidiabetik sehingga lansia lebih dapat mempertahankan fungsi kognitifnya.

Hasil analisis hubungan antara usia dengan fungsi kognitif lansia mendapatkan nilai $\mathrm{p}>0,05$ yang berarti tidak terdapat hubungan bermakna antara usia dengan fungsi kognitif. Penelitian terdahulu menyebutkan bahwa usia yang lebih tua berhubungan bermakna dengan nilai kemampuan kognitif yang lebih kecil. Seiring dengan bertambahnya usia maka kejadian demensia akan semakin bertambah. Kejadian demensia akan meningkat dua kali lipat setiap 5 tahun, dan terus meningkat hingga berusia sangat tua. ${ }^{19}$ Perubahan fungsi kognitif yang terjadi pada lansia meliputi berkurangnya kemampuan fungsi intelektual dan berkurangnya efisiensi transmisi saraf di otak yang menyebabkan proses informasi melambat dan banyak informasi hilang selama transmisi. Penurunan menyeluruh pada fungsi sistem saraf pusat dipercaya sebagai kontributor utama perubahan kemampuan kognitif dan efisiensi pemrosesan informasi. Namun pada penelitian ini tidak didapatkan hasil yang selaras dengan teori, yang mungkin akibat berbagai faktor lainnya yang dapat memengaruhi seperti lingkungan dan gaya hidup (pola makan dan aktivitas fisik).

\section{SIMPULAN}

Terdapat hubungan bermakna antara pola konsumsi minuman berkafein dengan fungsi kognitif lansia yang dinilai menggunakan MMSE, tetapi tidak terdapat hubungan bermakna dengan fungsi kognitif lansia yang dinilai menggunakan CDT.

Bagi penelitian selanjutnya disarankan untuk mengukur kadar kafein yang dikonsumsi sehingga didapatkan hasil yang lebih akurat. Selain itu dapat juga menggunakan metode lain seperti kasus kontrol dan kohort prospektif sehingga dapat mengikuti perkembangan kondisi pasien sebagai subyek penelitian.

\section{Konflik Kepentingan}

Penulis menyatakan tidak terdapat konflik kepentingan dalam studi ini.

\section{DAFTAR PUSTAKA}

1. Sundariyati IAH, Ratep N, Westa W. Gambaran faktor-faktor yang mempengaruhi status kognitif pada lansia di wilayah kerja Puskesmas Kubu II, Januari-Februari 2014. E-Jurnal Medika Udayana. Apr 2015. Available from: https://ojs.unud. ac.id/index.php/eum/article/view/12634

2. Manurung $\mathrm{CH}$, Karema W, Maja J. Gambaran fungsi kognitif pada lansia di Desa Koka Kecamatan Tombulu. e-CliniC. 2016; 4(2).

3. Logsdon RG, Gibbons LE, McCurry SM, Ter, L. (2017). Assessing quality of life in older adults with cognitive impairment. Psychosomatic Medicine. https://doi. org/10.1097/00006842-20020500000016

4. Panza F, Solfrizzi,V, Barulli MR, Bonfiglio C, Guerra V, Osella A, et al. Coffee, tea, and caffeine consumption and prevention of late-life cognitive decline and dementia: A systematic review. J Nutr Health Aging. 2015;19(3):313-28.

5. Chester N. Caffeine. In: Drugs in Sport (7th ed). 2018. Available from: https://doi.org/ 10.4324/9781315222790

6. Eskelinen, MH, Kivipelto M. Caffeine as a protective factor in dementia and Alzheimer's disease. J Alzheimer Dis. 2015;20(Suppl. 1):S167-74.

7. Sachio KD. Hubungan antara konsumsi kafein dan fungsi kognitif pada lanjut usia 
[Skripsi]. Jakarta: Universitas Trisakti, 2018.

8. Çakır ÖK, Ellek N, Salehin N, Hamamcı R, Keleş H, Kayalı DG, et al. Protective effect of low dose caffeine on psychological stress and cognitive function. Physiology and Behavior. 2017;168:110.

9. West RK, Ravona-Springer R, Livny A, Heymann A, Shahar D, Leroith, D, et al. Age modulates the association of caffeine intake with cognition and with gray matter in elderly diabetics. J Gerontol A Biol Sci Med Sci. 2019; 74(5):683-8.

10. Zhou A, Taylor AE, Karhunen V, Zhan Y, Rovio SP, Lahti J, et al. Habitual coffee consumption and cognitive function: A Mendelian randomization meta-analysis in up to 415,530 participants. Scientific Reports. 2018;8(1):1-9.

11. Perry CS, Thomas A., Taylor HA, Jacques PF, Kanarek RB. The impact of caffeine use across the lifespan on cognitive performance in elderly women. Appetite. 2016;107:69-78.

12. Maryam RS, Hartini T. Hubungan tingkat pendidikan dan activity daily living. Jurnal Kesehatan. 2015;1(23):45-55.

13. Dema BDJ, Sudarma V. Hubungan status gizi dan penurunan fungsi kognitif pada lansia. Seminar Nasional Pakar 2018 Buku 1. 2615-2584 pISSN, 2615-3343 eISSN.

14. James PA, Oparil S, Carter BL, Cushman WC, Dennison-Himmelfarb C, Handler J, et al. 2014 Evidence-based guideline for the management of high blood pressure in adults: Report from the panel members appointed to the Eighth Joint National Committee (JNC 8). JAMA. 2014;311(5): 507-20.

15. Powers RE. The Primary Care Guide of Cerebrovascular Prevention Strategies for Dementia. Bureau of Geriatric Psichiatry, 2006; p. 1-14. Available from: http://alzbrain.org/pdf/2513_11.pdf

16. Rouch L, Cestac P, Hanon O, Cool C, Helmer $\mathrm{C}$, Bouhanick B, et al. Antihypertensive drugs, prevention of cognitive decline and dementia: A systematic review of observational studies, randomized controlled trials and meta-analyses, with discussion of potential mechanisms. CNS Drugs. 2015;29(2):113-30.

17. Tsalissavrin I, Tritisari KP, Handayani D, Kusumastuty I, Ariestiningsih AD, Armetristi F. Hubungan lama terdiagnosa diabetes dan kadar glukosa darah dengan fungsi kognitif penderita diabetes tipe 2 di Jawa Timur. Jurnal AcTion. 2018;3(1):28-33.

18. Nuchalida M. Hubungan lamanya menderita diabetes melitus tipe 2 dengan penurunan fungsi kognitif [Naskah Publikasi]. Surakarta: Universitas Muhammadiyah Surakarta; 2015.

19. Samodra YL, Rahmawati. Faktor-faktor yang mempengaruhi kemampuan kognitif pada lansia obesitas di Indonesia. Jurnal Gizi Klinik Indonesia. 2018;14(4):154. 